International Journal of Current Advanced Research

ISSN: O: 2319-6475, ISSN: P: 2319 - 6505, Impact Factor: SJIF: 5.995

Available Online at www.journalijcar.org

Volume 6; Issue 3; March 2017; Page No. 2363-2365

DOI: http://dx.doi.org/10.24327/ijcar.2017.2365.0010

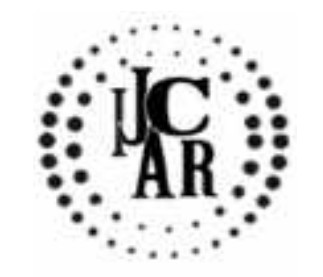

Research Article

\title{
QUALITY OF WORK LIFE REVISITED: A REVIEW OF RELATED LITERATURE
}

\section{Lenin Selvanayagam $\mathrm{B}^{1 *}$ and Thiyagarajan $\mathrm{M}^{2}$}

\author{
${ }^{1}$ Alagappa Institute of Management Studies, Karaikudi \\ ${ }^{2}$ Department of Business Administration, Alagappa Government Arts College, Karaikudi
}

\begin{tabular}{|c|c|}
\hline A R T T I C L E I I N F O & A B S T R A C T \\
\hline Article History: & The Quality of Work Life (QWL) has assumed increasingly interest and importance in all \\
\hline $\begin{array}{l}\text { Received } 8^{\text {th }} \text { December, } 2016 \\
\text { Received in revised form } 19^{\text {th }} \text { January, } 2017 \\
\text { Accepted } 12^{\text {th }} \text { February, } 2017 \\
\text { Published online } 28^{\text {th }} \text { March, } 2017\end{array}$ & $\begin{array}{l}\text { motivation, job performance and job satisfaction. It is also means to facilitate the } \\
\text { gratification of human needs and goal achievement. Work life naturally means the life of } \\
\text { workers, physical and intellectual, in their work environment in office or factory or field- } \\
\text { working. QWL involves wide varieties of components that are influenced on the } \\
\text { performance of employees, organisational commitment and job satisfaction. This paper }\end{array}$ \\
\hline d. & outcomes of that research. This will provide a limelight for the future research. \\
\hline
\end{tabular}

Quality of work life, Review literature

Copyright@2017 Lenin Selvanayagam B and Thiyagarajan M. This is an open access article distributed under the Creative Commons Attribution License, which permits unrestricted use, distribution, and reproduction in any medium, provided the original work is properly cited.

\section{INTRODUCTION}

A high quality of work life (QWL) is essential for organisations to continue to attract and retain employees. QWL is a comprehensive, department- wide program designated to improve employee satisfaction, strengthening workplace learning and helping employees had better manage change and transition. Dissatisfaction with quality work of life is a problem, which affects almost all workers regardless of position or status. Many managers seek to reduce dissatisfaction in all organizational levels, including their own. This is a complex problem, however, because it is difficult to isolate and identify all of attributes, which affect the quality of work life (Nasl Saraji \& Dargahi, 2006). This article reviews the burgeoning literature that pertains to Quality of work life in various organisations.

\section{Elements of Quality of Work Life}

Giang Thuy Phan, Trung Quang Vo (2016) concluded their research that the factors that affect QWL are job satisfaction, homework interface, working conditions, compensation, human relations, management personnel relations and support. Jindal Garima (2014) reported that the various factors the affect QWL are work environment, health and safety, job security, job satisfaction, job stress, work life balance and human relations. Sornalatha K. (2014) found out that the parameters for the quality of work life for the middle level managers in service industries in Chennai have slightly different from the usual parameters like job involvement,

*Corresponding author: Lenin Selvanayagam B

Alagappa Institute of Management Studies, Karaikudi performance appraisal, incentives etc. But the middle level managers have given priority to the communication chain and top management pressure along with the usual parameters. Valarmathi A. \& Hema Balakrishnan (2013) in their study states the factors influence quality of work life are fair compensation, healthy working conditions, safety, opportunities to develop human capabilities and opportunities for career growth as reported by the employees in textile industries in Coimbatore. Arul SenthilKumar S., Saravanaraj S.\& Punitha M.G.(2013) studied the QWL among the employees in supermarket in Coimbatore and reported that the employees identified health hazard free safe environment and work and grievance handling are the deciding point for QWL. Manoucher and et al (2013) found out the teachers' QWL lay on fair compensation, safe and healthy working condition and continued growth and security. Preethi Vijaimadhavan \& Venkatraman Raju D (2013) have identified 18 predominant factors which influence the Quality of work life. They are employee relationship, Work nature, Job autonomy, Job security, Work environment, Social environment, Psychological environment, Physical health, Depressive symptom, work stress, Work family interference, family work interference, Motivation, career satisfaction, interpersonal communication, efforts by employer, specified to job purpose and self-efficacy. Lokanadha Reddy. M, Mohan Reddy.(2013) discussed the dimensions of QWL include health and wellbeing, job security, job satisfaction, competence development and the balance between work and non work life. Shoeb Ahmad (2013) provides the basic element of QWL in any organization as the health and safety, employment security, job satisfaction, occupational stress, work environment, work-life balance and human relations. Chitraa.D, Mahalakshmi.V (2012) have used ten variables to measure Quality Work Life (QWL) are 
examined namely support from organization, work-family conflict, relationship with peers, self competence, impact on job, meaningfulness of job, optimism on organizational change, autonomy, access to resources and time control. Mohammed J, Almalki, Gerry Fitz Gerald and Michele Clark (2012) reported the major influencing factors were unsuitable working hours, lack of facilities for nurses, inability to balance work with family needs, inadequacy of vacations time for nurses and their families, poor staffing, management and supervision practices, lack of professional development opportunities, and an inappropriate working environment in terms of the level of security, patient care supplies and equipment, and recreation facilities (break-area). Other essential factors include the community's view of nursing and an inadequate salary. Seyyad Abolfazal \& el al, (2010) used an integrative review of the literature and identified six themes as the major predictors of the nurses' QWL: leadership and management style/decision-making latitude, shift working, salary and fringe benefits, relationship with colleagues, demographic characteristics, and workload/job strain. Rethinam, Guna Seelan and Ismail, Maimunah (2007) presented the constructs of QWL discussed are health and well-being, job security, job satisfaction, competency development, work and non-work life balance from the research they conducted among IT professionals.

\section{The Correlates of Quality of Work life}

Jalil Eslamian, Ali Akbar Akbarpoor, Sayed Abbas Hoseini (2015) found out that there was an inverse correlation between the quality of work and the frequency of exposures to workplace violence. Bayan Fatehi, Ismail Amini, Ali Karimi, Bisotoon Azizi (2015) showed that meaningful and positive relationship between the dimension of Quality of Work Life and Job Satisfaction in Sport Teachers in Department of Education from Urmia, Teheran. Baqer Shirazi Chrooan, Mohammad Reza Azadehdel, (2015) sum up the results that there is a significant correlation between the quality of work life and job satisfaction and Components of quality of working life can be a predictor of job satisfaction among managers. Fatihe Kermansarai, Ali Navidan, Shahindokhit Navabi Rigi and Fariba Yagharbinia (2015) concluded that there was a significant and positive correlation between job satisfaction of faculty members of Zahedan University of Medical Sciences and their quality of work life. Mohammad Rubiul Basher Rubel and Daisy Mui Hung Kee (2014) observed job satisfaction was found positively and significantly related with employee perception of Quality of Work life. Mohammad Hossein Nekouei et al (2014) gave the results of their study showed that: quality of work life was significantly influenced on job satisfaction; managerial dimensions of quality of work life make a better predictor for job satisfaction among employees in government organizations. Gayathri \& Lalitha Ramakrishnan (2013) found out a linkage between quality of work life and Job Satisfaction among hospital personalities. Sivarethinamohan R (2013) reported that QWL is positively nurture a more flexible, loyal, and motivated workforce, which are essential in determining the company's competitiveness in private banking sector. Hassan, Golkar (2013) reported that team spirit and organisational commitment are the two aspects of QWL have positive impacts on the Job satisfaction.

Heydar Mohammadia and Mohsen Ameri Shahrabi (2013) studied on relationship between quality of work life and job satisfaction of Government employee in Iran. The results of survey have confirmed that there were some meaningful relationships between the quality of work life on job satisfaction in both organizations. Pallavi, Kulkarni.P, (2013) focuses and analyse the literature findings on importance of training and development and its relation with the employees' quality of work life. Khadije Rahmaty Nia, Maryam Maleki (2013) found out that there is a significant and positive relationship between the quality of work life and organizational commitment. Chitraa.D, Mahalakshmi.V (2012) reported that QWL variables (meaningfulness of job, optimism on organizational change and autonomy) are significantly related to Job Satisfaction. Shalini Sheel, Bhawna Khosla Sindhwani, Shashank Goel, Sunil Pathak (2012) reviewed studies which predict that employee performance is also correlated with QWL. Farideh Haghshenas Kashani (2012) applied One-way Variance Analysis and concluded that there is no meaningful relationship between demographic characteristics with quality of work life and organizational citizenship behaviour. Jayakumar.A, Kalaiselvi.K (2012) reported that there is positive and significant relationship between QWL and employees' job satisfaction.

Behnam Talebi, Mehdi Pakdel Bonab, Ghader Zemestani and Nasrin Aghdami1 (2012) obtain results reveal that there is a significant relationship between the variables of salary and benefits, job security healthy and secure work environment, autonomy at work, providing the basis for skills education, and determining the job development direction with the employees effectiveness among Banking personals. Noor and Abdullah (2012) and Koonmee et al. (2010) study indicate that there is a significant relationship between job satisfaction and quality of work life Sameer Ahmad Shalla, Asif Iqbal Fazili (2011) conclude the study that a strong association found between quality of work life and job satisfaction. Furthermore, the findings also point out a strong divergence in the perception of employees towards quality of work life and job satisfaction across gender and nature of job.

\section{OVER VIEW OF THE LITERATURE REVIEW AND CONCLUSION}

Review of previous studies gives a clear picture about the elements or the parameters which determine the quality of work life in various organisations and by various respondents. In almost all the studies the elements of QWL identified are job security, work environment, compensation, human relations at work place, career growth and grievance handling. The major correlate of QWL is Job Satisfaction. At least twelve studies proved that there is positive correlation between QWL and Job Satisfaction. The other correlates are organisational commitment, workplace violence, employee performance, training and development and organisational citizenship behaviour. Moreover in these studies factor analysis, differential analysis, association analysis and correlation analysis were used. The review of these studies is helpful in determining the elements to be selected to study QWL and the variable to be correlated. This article of review of related literature will be an eye opener for the researchers in human resource management.

\section{References}

Arulsenthilkumar S. Saravanaraj M.G. Punitha a N, Quality of work life for employees in super markets with reference to 
Coimbatore, Abhinav, National Monthly refereed journal of research in commerce and Management, Vol 1 Issue 2.

Baqer Shirazi Chooran \& Mohammad Raza Azadahdel (2015) Quality of work life and its role in job satisfaction of organized Managers Cunchuriyet University Science Journal, Vol 36, No. 3 PP 258 - 266.

Bayan Fatchi Ismail Amini Ali Karimi, Brisotoon Azizi (2015) Impact of Quality of work life on job satisfaction, Research Journal of Sport Sciences Vol. 3 Issue I PP No 15-22.

Chitra Dr.Mahalakshmi V., A study on Employees Perception on quality of work life and Job satisfaction in Manufacturing organization an empirical study, International Journal of Trade and commerce Vol.No. 1 Issue No 2, July Dec 2012, PP 175 - 184.

Farideh Hagshenas Kashani, A Review on Relationship between quality of work life and organizational citizenship behaviours. Journal of Bank and applied scientific Research, Vol 2, Issue 9, 2012.

Fatihe Kermanaravi, Ali Navidian Shahindokhit Navabi Rigi and Fariba Yaghabinia (2015) Relationship between quality of work life and job satisfaction of faculty members in Zahedan University of Medical Sciences, Global Journal of Health Science Vol 7 Is 2 March 2015 PP 228 - 234.

G.Nasl Saraji, H Dargahi (2006) Study of quality of work life, Iranian Journal of public health 35 (4) 8-14.

Gayathiri R. Lalitha Ramakrishnan (2013) Quality of work life - Linkage with job satisfaction and work performance. International Journal of Business and Management Invention. Vol 2 Issue I January 2013 PP $1-8$.

Giang Thuy Phan, Trung Quang Vo (2016) A Literature Review on Quality of Work life: A case of Health Care workers, Journal of applied Pharmaceutical Science Vol 6 . Issue 7 PP 193-200 July 2016.

Hassan, Golkar (2013) The relationship between OWL and Job satisfaction A survey of human resource managers in Iran, Interdisciplinary Journal of Contemporary Research in Business Vol 5, No. 8 PP 215 - 224.

Heydar Mohammadia and Mohsen Ameri Shahsabi (2013) A study on relationship between Quality of Work life and Job Satisfaction, Management Science Letters 3, PP 2675 - 2680

Indra Kandasami \& Sreekumar Ancheri (2009) Hotel employer expectations of QWL: A qualitative study, International Journal of Hospitality Management, Volume 28, Issue 3 Sept 2009 328-339.

Jalil Eslamian, Ali Akbar Akbarpoor Sayed Abbas Hoseini (2015) Quality of Work life and its association with workplace violence of the nurses in emergency departments, Iranian Journal of Nursing and Midwifery Research, Vol 20 Issue I Jan - Feb 2015.

Jeyakumar A Kalaiselvi (2012) Quality of Work life An overview, International Journal of Marketing Finance Service and Management research, Vol I, Issue10, PP No $-140-151$

Jindal Garima (2014) Factors affecting Quality of Work life ACA DEMICIA : A International Multidisciplinary Research Journal, Vol 4, Issue 4 Page 216-221.

Koonmee, K., Singhapakdi, A., Virakul, B., \& Lee, D.-J. (2010). Ethics institutionalization, quality of work life and employees jobrelated outcomes: A survey of human resource managers in Thailand. Journal of Business Research, 63, 20-26.

Lokanadha Reddy M Mohan Reddy (2013) Quality of work life of employed emerging dimensions, Asian Journal of Management Research, Vol No, Issue No, Page No $827-839$

M.Pallavi P. Kulkarni (2013) A literature Review on training \& Development and quality work life, Researcher's. world Journal of Art Sciences \& Commerce, Vol 4 Issue, April 2013

Manoucheehr et al., (2013) The Relationship Between EFL Teachers' Quality of Work Life and Job Motivation, Middle East Journal of scientific Research 13 (3)

Mohammad Hossein Nekouei et al (2014) Quality of Work life and job Satisfaction among employees in Govt. Organisations in IRAN, Journal of basic and applied scientific research, Vol,4 Issue 1, PP No 217 - 299.

Mohammad Rubiul Baher Rubel and Daisy Muittung Kee (2014) Quality of work life and employee performance antecedent and out come of job satisfaction in partial least square, World Applied Science Journal, Vol 31, Issue 4 ,Page 456 - 467

Mohammed J Almalki Gessi Fitz Gerald (2012) Qualify of Work life among primary health care nurses in the Jazan region South Arabia, Human Resources for health, Sep 2012.

Noor, S. M., \& Abdullah, M. A. (2012). Quality Work Life among Factory Workers in Malaysia. Procedia - Social and Behavioral Sciences, 35, 739-745.

Preethi Vijaimadheva Venkat Raju (2013) An empirical study in relationship among quality of work life and its factors, Journal of Business and Management, Vol 12, Issue 3, July - Aug, PP 20-28

Rethinam Guna Seelan and Ismail Maimunah (2007) Constructs of quality of work life A perspective of Information and Technology Professional, European Journal of Social Science, Vol 7, Issue 1, PP 58-70

Seyyad Adolfazl vagharseyyedia, Zohrch vanaki Eesa Mohammodi An integrative Review of Literature Western journal of Nursing research. August 18, Sage journals, 2010.

Shalini Sheela, Bhawna Khosla Sindhwani, Shashank Goel, Sunil Pathak, Quality work life Employee Performance and career Growth opportunities : A Literature Review International Journal of Multidisciplinary Research, Vol 2, Issue 2, Feb 2012

Sholb Ahmad (2013) Paradigams of Quality of Work life Journal of Human Values, Sage Journal Vol 19 Issue I Page No

Sivarathinamohan R (2013) Effect of quality of work life on employee retention on private sector banks International center for business research volume 2 Issue 04 Page 126135

Sornalatha K (2014) An analytical study of quality of work life of the middle level manages in service Industries in Tamilnadu, The international Journal of Management Vol, 3 Issue - 1 Jan 2014 - 04 -11.

Valarmathi and Hema Balakrishnan, Quality of Work Life In Textile Sector In And Around Coimbatore District, Journal of Business Management and Social Science Review, Vol2, No.2, Feb.2013 